\title{
FAKTOR RISIKO OBESITAS IBU RUMAH TANGGA DI KELURAHAN BENDUNGAN KECAMATAN GAJAHMUNGKUR KOTA SEMARANG
}

\author{
Linda Apriaty, Nuryanto*) \\ Program Studi Ilmu Gizi Fakultas Kedokteran Universitas Diponegoro \\ Jl.Dr.Sutomo No.18, Semarang, Telp (024) 8453708, Email : gizifk@ undip.ac.id
}

\begin{abstract}
ABSTRACK
Background: Obesity is a condition where there is abnormal or excessive fat accumulation in the body, indicated with $B M I \geq 25 \mathrm{~kg} / \mathrm{m}^{2}$. The prevalence of obesity in Indonesia increase each year especially in women. Obesity risk factors include physical activity, energy intake, carbohydrate intake, fat intake, protein intake, use of hormonal contraception, and family economic status. The aimed of this study is to analyzed the risk factor of obesity.

Method: Observational study with case control design the subjects are housewife at RW 02 Bendungan Village Gajahmungkur Sub District Semarang. Sample was selected by consecutive sampling with 30 subjects each group. Degrees obesity are expressed by BMI. Subject identity, use of hormonal contraception, and family economic statuswere acquired using questionnaire. Energy intake, carbohydrate intake, fat intake, protein intake were acquired using Food Frequency Questionnaire (FFQ) and physical activity was acquired using International Physical Activity Questionnaire (IPAQ). Data were analyzed with Chi-square to determining Odds Ratio (OR).

Results: Risk factor obesity among housewife was low physical activity $(O R=5.500 ; C l$ 1.813-16.681; $p=0.002)$, excess energy intake $(O R=8.636 ; C I$ 2.566-29.073; $p=0.000)$, and excess carbohydrate intake $(O R=8.636 ; C I$ 2.566-29.073; $p=0.000)$. Fat intake, protein intake, use of hormonal contraception, and family economic status were non-significant risk factor.

Conclusion: Low physical activity, excess energy intake, and excess carbohydrate intake are significant risk factor obesity among housewife.
\end{abstract}

Keywords: Obesity, physical activity, energy intake, carbohydrate intake, housewife

\section{ABSTRAK}

Latar Belakang: Obesitas merupakan sebuah keadaan dimana terjadi ketidaknormalan atau kelebihan akumulasi lemak dalam tubuh, ditunjukan dengan IMT $\geq 25 \mathrm{~kg} / \mathrm{m} 2$. Prevalensi obesitas di Indonesia meningkat tiap tahunnya terutama pada wanita. Faktor risiko obesitas antara lain aktivitas fisik, asupan energi, asupan karbohidrat, asupan lemak, asupan protein, penggunaan alat kontrasepsi hormonal, dan status ekonomi keluarga. Tujuan penelitian ini adalah mengetahui faktor risiko obesitas ibu rumah tangga.

Metode: Penelitian observational dengan desain case-control pada ibu rumah tangga di RW 02 Kelurahan Bendungan Kecamatan Gajahmungkur Kota Semarang. Pengambilan sampel dilakukan dengan consecutive sampling, 30 subjek pada tiap kelompok. Obesitas dikategorikan berdasarkan nilai IMT. Data identitas subjek, penggunaan alat kontrasepsi hormonal, dan status ekonomi keluargadiperoleh melalui kuesioner. Data asupan energi, karbohidrat, lemak, dan protein diperoleh melalui Food Frequency Questionnaire (FFQ) dan data aktivitas fisik diperoleh melalui International Physical Activity Questionnaire (IPAQ). Analisis menggunakan metode Chi Square dengan melihat Odds Ratio (OR).

Hasil: Faktor risiko obesitas ibu rumah tangga adalah aktivitas fisik rendah $(O R=5.500 ;$ Cl 1.813-16.681; $p=$ 0.002), asupan karbohidrat lebih (OR = 8.636; CI 2.566-29.073; $p=0.000)$, asupan karbohidrat lebih $(O R=4.030$; CI 1.372-11.839; $p=0.010$. Asupan lemak, asupan protein, penggunaan alat kontrasepsi hormonal, dan status ekonomi keluarga bukan merupakan faktor risiko kejadian obesitas.

Kesimpulan: Aktivitas fisik rendah, asupan energi lebih, dan asupan karbohidrat lebih merupakan faktor risiko yang bermakna pada kejadian obesitas ibu rumah tangga.

Kata kunci: obesitas, aktivitas fisik, asupan energi, asupan karbohidrat, ibu rumah tangga

\section{PENDAHULUAN}

Obesitas adalah sebuah keadaan dimana terjadi ketidaknormalan atau kelebihan akumulasi lemak dalam tubuh. World Health Organization (WHO) menyebutkan kurang lebih 2,8 juta orang meninggal setiap tahunnya karena obesitas, dan menjadi penyebab kematian nomor lima didunia. ${ }^{1}$ Seseorang yang obesitas dapat meningkatkan risiko penyakit tidak menular seperti diabetes 4.5 kali, hipertensi 2.5 kali, dan penyakit jantung koroner sebanyak 32\%. ${ }^{2-4}$ Studi tahun 2009 yang dilakukan oleh Research Triangle Institute dan Center for Disease Control and Prevention (CDC) menyebutkan Amerika Serikat mengeluarkan biaya $\$ 147.000 .000 .000$,- per tahun untuk membiayai perawatan kesehatan yang terkait dengan obesitas. ${ }^{5}$

Prevalensi obesitas di dunia meningkat dua kali lipat dari tahun 1980 sampai 2008. Tahun 2008

${ }^{*}$ Penulis Penanggungjawab 
prevalensi obesitas wanita dan pria dewasa sebesar $14 \%$ dan $10 \%$ di dunia. Kejadian obesitas meningkat seiring dengan peningkatan usia dan mencapai puncaknya saat dewasa. ${ }^{6,7}$ Prevalensi obesitas pada orang dewasa di Indonesia $15,4 \%$ lebih tinggi dibandingkan prevalensi obesitas pada anak yaitu $8,8 \%$. Obesitas pada dewasa lebih banyak terjadi pada wanita. Jika dilihat dari trend kenaikan prevalensi obesitas pada wanita dewasa selalu mengalami kenaikan tiap tahunnya, dimana pada tahun 2007 prevalensi obesitas pada wanita dewasa sebesar $13,9 \%$, tahun 2010 prevalensinya sebesar $15,5 \%$, dan tahun 2013 prevalensinya sebesar 32,9\%. ${ }^{8-10}$ Prevalensi obesitas pada wanita dewasa di Jawa Tengah sebesar $21,7 \%$. Kota Semarang memiliki prevalensi obesitas pada wanita dewasa sebesar 22,3\%. ${ }^{8}$

Faktor yang mempengaruhi kejadian obesitas pada ibu rumah tangga diantaranya aktivitas fisik yang rendah. Penelitian yang dilakukan tahun 2014 yang dilakukan pada $200 \mathrm{ibu}$ rumah tangga menyebutkan aktivitas fisik yang rendah menjadi faktor risiko obesitas pada ibu rumah tangga. ${ }^{11}$ Meningkatkan aktivitas fisik 45-60 menit sehari dapat mencegah kejadian obesitas. ${ }^{12}$ Setiap penurunan 1 poin dari skor penilaian aktivitas fisik akan meningkatkan IMT sebesar 1,25 $\mathrm{kg} / \mathrm{m}^{2}{ }^{13}$

Faktor lain yang mempengaruhi obesitas pada ibu rumah tangga adalah asupan energi yang lebih besar dibanding dengan energy expenditure (keluaran energi) dalam jangka waktu yang lama. ${ }^{14}$ Asupan energi yang berlebih akan meningkatkan risiko seseorang mengalami obesitas. . $^{15,16,17}$ Seringnya mengkonsumsi makanan dalam jumlah berlebih baik karbohidrat, lemak, dan protein dapat menyebabkan terjadinya obesitas. Penelitian yang dilakukan pada wanita dewasa menyatakan bahwa tingginya asupan energi tanpa diimbangi dengan aktivitas fisik akan menyebabkan penyimpanan energi ekstra sebagai lemak dan mengakibatkan obesitas. ${ }^{18,19}$ Hasil penelitian kohort selama 7 tahun menunjukkan bahwa orang yang mengonsumsi pangan sumber protein hewani berisiko terkena obesitas sebesar 4.62 kali. $^{20}$ Penelitian di Georgia State University menyatakan bahwa peningkatan berat badan terjadi karena kelebihan konsumsi karbohidrat dan lemak. ${ }^{21}$

Penggunaan alat kontrasepsi hormonal (suntik, pil, dan implant) pada ibu rumah tangga menyebabkan kenaikan berat badan pada beberapa penelitian, hal ini disebabkan oleh peningkatan hormon esterogen dan progestin dalam tubuh yang menyebabkan retensi cairan dan meningkatkan nafsu makan sehingga dapat meningkatkan berat badan. $^{22,23}$

Salah satu wilayah di Jawa Tengah dengan prevalensi obesitas tinggi adalah Kota Semarang. Tujuan penelitian ini adalah mengetahui pengaruh faktor risiko aktivitas fisik, asupan energi, asupan karbohidrat, asupan lemak, asupan protein, asupan serat, penggunaan alat kontrasepsi hormonal, dan status ekonomi keluarga terhadap kejadian obesitas ibu rumah tangga.

\section{METODE}

Penelitian ini dilakukan di Kelurahan Bendungan Kecamatan Gajahmungkur Kota Semarang. Jenis penelitian observasional dengan rancangan case-control. Subjek dalam penelitian ini adalah semua kasus dan kontrol yang dipilih dengan perbandingan 1:1. Kelompok kasus adalah ibu rumah tangga dengan IMT (Indeks Massa Tubuh) $\geq$ $25,0 \mathrm{~kg} / \mathrm{m}^{2}$, sedangkan kelompok kontrol adalah ibu rumah tangga dengan IMT $18,5-22,9 \mathrm{~kg} / \mathrm{m}^{2}{ }^{24}$ Jumlah sampel pada masing-masing kelompok sebanyak 30 responden. Kriteria inklusi dalam penelitian ini adalah ibu rumah tangga berusia 2045 tahun, belum menopause, tidak sedang diet, dan tidak sedang hamil. Variabel terikat dalam penelitian ini adalah obesitas, sedangkan variabel bebas adalah aktivitas fisik, asupan energi, asupan karbohidrat, asupan lemak, asupan protein, penggunaan alat kontrasepsi hormonal, status ekonomi keluarga, riwayat obesitas.

Aktivitas fisik adalah kegiatan fisik yang dilakukan subjek yang diperoleh melalui formulir International Physical Activity Questionnaire (IPAQ). Skor aktivitas fisik diperoleh berdasarkan jenis aktivitas dikalikan dengan frekuensi dan durasi aktivitas fisik yang dilakukan subjek selama 7 hari. Aktivitas fisik digolongkan rendah apabila skor aktivitas < $3000 \mathrm{MET}$-menit/minggu, aktivitas fisik digolongkan berat apabila skor aktivitas $\geq$ 3000 MET-menit/minggu. ${ }^{25}$

Asupan energi adalah jumlah asupan energi rata-rata per hari dari konsumsi makanan dan minuman dengan satuan kkal per hari dan diukur menggunakan metode formulir Food Frequency Questionnaire (FFQ). Hasil yang diperoleh dibandingkan dengan AKG (Angka Kecukupan Gizi), dan dikategorikan menjadi cukup $(\leq 100 \%$ AKG), lebih (>100\% AKG).

Asupan karbohidrat adalah jumlah asupan karbohidrat rata-rata per hari dari konsumsi makanan dan minuman dengan satuan gram per hari dan diukur menggunakan metode formulir Food Frequency Questionnaire (FFQ). Hasil yang diperoleh dibandingkan dengan AKG (Angka 
Kecukupan Gizi), dan dikategorikan menjadi cukup $(\leq 100 \%$ AKG), lebih (>100\% AKG.

Asupan lemak adalah jumlah asupan lemak rata-rata per hari dari konsumsi makanan dan minuman dengan satuan gram per hari dan diukur menggunakan metode formulir Food Frequency Questionnaire (FFQ). Hasil yang diperoleh dibandingkan dengan AKG (Angka Kecukupan Gizi), dan dikategorikan menjadi cukup $(\leq 100 \%$ AKG), lebih (>100\% AKG).

Asupan protein adalah jumlah asupan protein rata-rata per hari dari konsumsi makanan dan minuman dengan satuan gram per hari dan diukur menggunakan metode formulir Food Frequency Questionnaire (FFQ). Hasil yang diperoleh dibandingkan dengan AKG (Angka Kecukupan Gizi), dan dikategorikan menjadi cukup ( $\leq 100 \%$ AKG), lebih (>100\% AKG).

Asupan serat adalah jumlah asupan serat rata-rata per hari dari konsumsi makanan dan minuman dengan satuan gram per hari dan diukur menggunakan metode formulir Food Frequency Questionnaire (FFQ). Hasil yang diperoleh dibandingkan dengan AKG (Angka Kecukupan Gizi), dan dikategorikan menjadi cukup $(\leq 100 \%$ AKG), lebih (>100\% AKG).

Penggunaan alat kontrasepsi hormonal merupakan status subjek menggunakan alat kontrasepsi hormonal. Dikategorikan menjadi menggunakan alat kontrasepsi hormonal apabila menggunakan alat kontrasepsi jenis suntik, pil, dan implan. ${ }^{26}$ Status ekonomi keluarga merupakan pendapatan perbulan yang diperoleh semua anggota keluarga dan dikategorikan berdasarkan Upah Minimum Regional (UMR) Kota Semarang tahun 2015. Status keluarga menengah kebawah apabila pendapatan keluarga $\leq \mathrm{Rp} 1.685 .000$,- dan status keluarga dinyatakan tinggi apabila pendapatan keluarga > Rp 1.685.000, ${ }^{27}$

Analisis statistik untuk mengetahui pengaruh faktor risiko aktivitas fisik, asupan energi, asupan karbohidrat, asupan lemak, asupan protein, penggunaan alat kontrasepsi hormonal, status ekonomi keluarga, dan riwayat obesitas terhadap kejadian obesitas menggunakan Chi Square yaitu dengan melihat Odd Ratio (OR).

\section{HASIL PENELITIAN \\ Karakteristik Subjek}

Subjek yang masuk memenuhi kriteria inklusi sebanyak 64 ibu rumah tangga. Saat pengambilan data 3 subjek dari kelompok kasus dan 1 subjek dari kelompok kontrol drop out karena tidak bisa ditemui saat pengambilan data lanjutan, sehingga jumlah subjek sebanyak 60 ibu rumah tangga, 30 ibu rumah tangga masing-masing kelompok. Adapun karakteristik subjek sebagai berikut.

Tabel 1. Distribusi frekuensi usia

\begin{tabular}{lccc}
\hline \multicolumn{1}{c}{ Usia } & Kasus & Kontrol & $P$ \\
\hline Mean & 35.1 & 33.7 & \\
Standar Deviasi & 6.6 & 5.8 & $0.373^{\mathrm{a}, \mathrm{b}}$ \\
$\mathrm{n}$ & 30 & 30 & \\
\hline
\end{tabular}

${ }^{\mathrm{a}}$ : Independent t-test ${ }^{\mathrm{b}}: p>0.05$

Tabel 1 menunjukan tidak ada perbedaan berdasarkan rerata usia pada kedua kelompok, dimana rerata umur pada kelompok kasus 35,1 \pm 6,6 dan kelompok kontrol 33,7 $\pm 5,8$. Analisa univariat dilakukan untuk melihat median dan nilai minimalmaksimal.

Tabel 2. Tabel deskriptif aktivitas fisik, asupan energi, asupan karbohidrat, asupan lemak, asupan protein, status ekonomi keluarga

\begin{tabular}{llcc}
\hline & \multicolumn{1}{c}{ Variabel } & Kasus & Kontrol \\
\hline 1 & Aktivitas fisik (MET-menit/minggu) & & \\
& $-\quad$ Median & 2285.63 & 3262.9 \\
& $-\quad$ Minimum & 1196.0 & 1134.5 \\
& $-\quad$ Maksimul & 3460.5 & 3681.0 \\
\hline 2 & Asupan energi (kkal) & & \\
& $-\quad$ Median & 2377.7 & 2137.15 \\
& $-\quad$ Minimum & 1985.3 & 1671.1 \\
& $-\quad$ Maksimum & 2810.5 & 2498.1 \\
\hline 3 & Asupan karbohidrat (gram) & & \\
& $-\quad$ Median & 333.8 & 270.85 \\
\hline
\end{tabular}




\begin{tabular}{|c|c|c|c|}
\hline & $\begin{array}{ll}\text { - } & \text { Minimum } \\
\text { - } & \text { Maksimum }\end{array}$ & $\begin{array}{l}242.1 \\
398.8\end{array}$ & $\begin{array}{l}210.9 \\
359.7\end{array}$ \\
\hline \multirow[t]{4}{*}{4} & Asupan lemak (gram) & & \\
\hline & - Median & 84.75 & 72.55 \\
\hline & - Minimum & 51.1 & 49.6 \\
\hline & - Maksimum & 105.6 & 94.5 \\
\hline \multirow[t]{4}{*}{5} & Asupan protein (gram) & & \\
\hline & - Median & 73.95 & 56.75 \\
\hline & - $\quad$ Minimum & 46.2 & 45.6 \\
\hline & - $\quad$ Maksimum & 92.8 & 84.2 \\
\hline \multirow[t]{4}{*}{6} & Asupan serat (gram) & & \\
\hline & - Median & 15.3 & 25.4 \\
\hline & - $\quad$ Minimum & 5.4 & 6.7 \\
\hline & - Maksimum & 27.9 & 27.4 \\
\hline \multirow[t]{4}{*}{7} & Status ekonomi keluarga (rupiah) & & \\
\hline & - Median & 1.900 .000 & 1.667 .500 \\
\hline & - $\quad$ Minimum & 1.200 .000 & 700.000 \\
\hline & - $\quad$ Maksimum & 5.000 .000 & 4.500 .000 \\
\hline
\end{tabular}

\section{Faktor Risiko Obesitas}

Hasil uji Chi Square untuk melihat faktor risiko terjadinya obesitas pada ibu rumah tangga, dapat dilihat dalam tabel 3 berikut.

Tabel 3. Faktor risiko aktivitas fisik, asupan energi, asupan karbohidrat, asupan lemak, asupan protein, penggunaan alat kontrasepsi hormonal, dan status ekonomi keluarga

\begin{tabular}{|c|c|c|c|c|c|c|c|c|}
\hline & & & sus & & ntrol & & & \\
\hline & Varıabel & $\mathrm{N}$ & $\%$ & $\overline{\mathrm{N}}$ & $\%$ & OR & С195\% & $P$ \\
\hline 1 & Aktivitas fisik & & & & & & & \\
\hline & - Rendah & 22 & $73.3 \%$ & 10 & $33.3 \%$ & 5.500 & $1.813-16.681$ & $0.002^{\mathrm{a}, \mathrm{b}}$ \\
\hline & - $\quad$ Tinggi & 8 & $26.7 \%$ & 20 & $66.7 \%$ & & & \\
\hline 2 & Asupan energy & & & & & & & \\
\hline & - Lebih & 25 & $83.3 \%$ & 11 & $36.7 \%$ & 8.636 & $2.566-29.073$ & $0.000^{\mathrm{a}, \mathrm{b}}$ \\
\hline & - Cukup & 5 & $16.7 \%$ & 19 & $63.3 \%$ & & & \\
\hline 3 & Asupan karbohidrat & & & & & & & \\
\hline & - Lebih & 19 & $63.3 \%$ & 9 & $30.0 \%$ & 4.030 & $1.372-11.839$ & $0.010^{\mathrm{a}, \mathrm{b}}$ \\
\hline & - Cukup & 11 & $36.7 \%$ & 21 & $70.0 \%$ & & & \\
\hline 4 & Asupan lemak & & & & & & & \\
\hline & - Lebih & 25 & $83.3 \%$ & 18 & $60.0 \%$ & 3.333 & $0.998-11.139$ & $0.045^{\mathrm{a}, \mathrm{b}}$ \\
\hline & - Cukup & 5 & $16.7 \%$ & 12 & $30.0 \%$ & & & \\
\hline 5 & Asupan protein & & & & & & & \\
\hline & - Lebih & 20 & $66.7 \%$ & 15 & $50.0 \%$ & 2.000 & $0.705-5.677$ & $0.190^{\mathrm{a}}$ \\
\hline & - Cukup & 10 & $33.3 \%$ & 15 & $50.0 \%$ & & & \\
\hline 6 & Asupan serat & & & & & & & \\
\hline & - Rendah & 21 & $70.0 \%$ & 13 & $43.3 \%$ & 3.051 & $1.053-8.839$ & $0.037^{\mathrm{a}, \mathrm{b}}$ \\
\hline & - Cukup & 9 & $30.0 \%$ & 17 & $56.7 \%$ & & & \\
\hline 7 & Penggunaan alat & & & & & & & \\
\hline & kontrasepsi hormonal & & & & & 0.857 & $0.288-2.547$ & $0.781^{\mathrm{a}}$ \\
\hline & $-\mathrm{Ya}$ & 20 & $66.7 \%$ & 21 & $70.0 \%$ & 0.051 & $0.200-2.541$ & \\
\hline & - $\quad$ Tidak & 10 & $33.3 \%$ & 9 & $30.0 \%$ & & & \\
\hline 8 & $\begin{array}{l}\text { Status ekonomi } \\
\text { keluarga }\end{array}$ & & & & & 2.615 & $0.917-7.457$ & $0.069^{\mathrm{a}}$ \\
\hline
\end{tabular}




\begin{tabular}{clllll}
\hline- & Rendah & 13 & $43.3 \%$ & 20 & $66.7 \%$ \\
- & Tinggi & 17 & $56.7 \%$ & 10 & $33.3 \%$ \\
\hline
\end{tabular}

${ }^{a}:$ Uji Chi Square, ${ }^{b}: p<0.05$

Tabel 3 menunjukan bahwa yang menjadi faktor risiko obesitas ibu rumah tangga adalah aktifitas fisik, asupan energi, asupan karbohidrat, dan asupan serat. Sementara asupan lemak, asupan protein, penggunaan alat kontrasepsi hormonal dan status ekonomi bukan merupakan faktor risiko obesitas ibu rumah tangga.

\section{PEMBAHASAN}

Penelitian ini didapatkan hasil bahwa aktivitas fisik merupakan faktor risiko obesitas ibu rumah tangga. Ibu rumah tangga yang memiliki aktivitas fisik rendah mempunyai risiko 5,5 kali menjadi obesitas dibandingkan dengan ibu rumah tangga yang memiliki aktivitas fisik tinggi. Penelitian lain juga menyebutkan setiap penurunan 1 poin dari skor aktivitas fisik dapat meningkatkan IMT sebesar $1,25 \mathrm{~kg} / \mathrm{m}^{2} .{ }^{13}$ Obesitas terjadi karena ketidakseimbangan energi yang masuk dengan energy expenditure. Aktifitas fisik dapat meningkatkan total energy expenditure (energi yang dikeluarkan) sehingga dapat mempertahankan keseimbangan energi didalam tubuh. Apabila energi tidak terpakai maka akan disimpan dalam bentuk asam lemak di jaringan adiposa. Meningkatknya jaringan adiposa ditubuh akan menyebabkan kenaikan berat badan yang dalam jangka panjang akan menjadi obesitas. ${ }^{28,29}$

Penelitian ini juga menyebutkan asupan energi merupakan faktor risiko obesitas ibu rumah tangga. Ibu rumah tangga yang memiliki asupan energi tinggi (>100\% AKG) akan berisiko 8,6 kali lebih besar menjadi obesitas dibandingkan dengan ibu rumah tangga yang memiliki asupan energi cukup $(\leq 100 \%$ AKG). Asupan energi diperoleh dari makanan dan minuman yang dikonsumsi tiap harinya. Asupan energi yang energi yang tinggi menyebabkan peningkatan simpanan energi didalam tubuh. Apabila simpanan energi tidak digunakan maka simpanan energi tersebut akan diubah menjadi lemak disimpan di jaringan adiposa yang dapat meningkatkan berat badan dan dalam jangka panjang akan menyebabkan obesitas. ${ }^{28}$

Asupan karbohidrat merupakan faktor risiko obesitas ibu rumah tangga. Ibu rumah tangga yang memiliki asupan karbohidrat lebih (>100\% AKG) berisiko 4 kali lebih besar menjadi obesitas dibandingkan dengan ibu rumah tangga yang memiliki asupan karbohidrat cukup ( $\leq 100 \% \mathrm{AKG})$. Karbohidrat yang dikonsumsi akan dipecah menjadi glukosa di usus halus. Glukosa didalam tubuh akan disimpan di hati dan otot dalam bentuk glikogen. Fungsi glikogen yang disimpan di hati dan otot berbebeda fungsinya, glikogen otot digunakan untuk mensintesis ATP untuk kontraksi otot, jumlah glikogen di otot tergantung pada aktivitas fisik yang dilakukan. Apabila seseorang melakukan aktivitas fisik tinggi simpanan glikogen akan diubah menjadi glukosa kembali selanjutnya akan dikatabolisme menjadi ATP/energi dalam siklus asam sitrat. Namun apabila seseorang mengkonsumsi karbohidrat tinggi dan memiliki aktivitas fisik rendah glikogen akan masuk ke siklus piruvat dan kemudian diubah menjadi Asetil-Koa yang berguna untuk mensintesis asam lemak. Sintesis asam lemak tersebut akan menghasilkan trigliserida yang kemudian disimpan dalam jaringan lemak, dalam jangka waktu panjang akan menyebabkan kenaikan berat badan. ${ }^{29}$

Makanan dan minuman yang mengandung lemak akan dicerna menjadi asam lemak dan gliserol. Asam lemak dimetabolisme menjadi asam piruvat yang kemudian dimetabolisme lagi menjadi asetil-KoA, sedangkan gliserol dimetabolisme menjadi asetil-KoA. Asetil-KoA kemudian masuk dalam siklus asam sitrat yang hasil akhirnya adalah ATP (energi), energi akan digunakan apabila aktivitas fisik seseorang tinggi namun apabila aktivitas fisik rendah energi akan diubah menjadi trigliserid dan disimpan dalam jaringan adiposa yang dalam jangka waktu yang panjang akan menyebabkan kenaikan berat badan. ${ }^{28}$ Hasil penelitian ini asupan lemak bukan merupakan faktor risiko obesitas ibu rumah tangga bertentangan dengan teori yang disebutkan diatas, hal ini dikarenakan asupan serat rendah pada ibu rumah tangga merupakan faktor risiko obesitas dengan $\mathrm{p}<0.05$. Asupan serat terbagi menjadi 2 yaitu serat larut air dan serat tidak larut air. Serat larut air mampu menghambat absorbsi lemak dalam usus halus, di saluran pencernaan serat larut air mengikat asam empedu untuk keluar bersama feses, serat larut air juga mampu meningkatkan ekskresi asam empedu. Apabila asam empedu meningkat maka penyerapan lemak dalam tubuh berkurang karena sebagian lemak akan beikatan dengan asam empedu keluar bersama feses. ${ }^{28,29}$

Penelitian ini menyatakan asupan protein bukan merupakan faktor risiko obesitas ibu rumah tangga. Karena konsumsi tinggi protein justru 
menjadi faktor protektif obesitas, penelitian pada tahun 2011 menyatakan asupan tinggi protein dapat meningkatkan rasa kenyang dibandingan dengan konsumsi karbohidrat dan lemak, hal ini diakibatkan aktivitas oksidasi asam amino. Selain itu Thermic Effect of Food (TEF) meningkat setelah mengkonsumi protein yaitu sebesar $20-35 \%$, tetapi hanya $5-10 \%$ setelah konsumsi karbohidrat, dan 0$5 \%$ setelah konsumsi lemak. ${ }^{30}$

Penggunaan alat kontrasepsi hormonal bukan merupakan faktor risiko obesitas ibu rumah tangga. Alat kontrasepsi hormonal dapat mempengaruhi nafsu makan dan retensi cairan yang dapat menyebabkan kenaikan berat badan. ${ }^{31}$ Penelitian ini tidak diketahui lama penggunaan alat kontrasepsi hormonal. Penggunaan alat kontrasepsi hormonal selama lebih dari satu tahun dapat meningkatkan 4,25 kali risiko kenaikan berat badan dibandingkan dengan penggunaan alat kontrasepsi hormonal kurang dari satu tahun. ${ }^{32}$

Ibu rumah tangga yang memiliki status ekonomi keluarga rendah lebih tinggi berisiko obesitas, hal ini disebabkan oleh pemilihan bahan makanan yang tinggi karbohidrat dan lemak yang cenderung lebih terjangkau. ${ }^{33}$ Namun hasil penelitian ini menunjukan status ekonomi keluarga bukan merupakan faktor risiko obesitas ibu rumah tangga. Hal ini dikarenakan ibu rumah tangga yang memiliki status ekonomi tinggi cenderung membeli dan mengkonsumsi makanan lebih banyak dibandingan dengan ibu rumah tangga yang memiliki status ekonomi rendah.

\section{SIMPULAN}

Aktivitas fisik, asupan energi, asupan karbohidrat, dan asupan serat merupakan faktor risiko obesitas ibu rumah tangga.

\section{DAFTAR PUSTAKA}

1. World Health Organization. Overweight and Obesity. 2013. Available from: http://www.who.int/mediacentre/factsheets/fs311/e $\underline{\mathrm{n} /}$

2. Kodama S, Horikawa C, Fujihara K. Quantitative relationship between body weight gain in adulthood and incident type 2 diabetes: a meta-analysis. Obes Rev 2014;15(3):202-14.

3. Mendez MA, Cooper RS, Luke A, Wilks R, Bennett F, \& Forrester T. 2004. Higher income is more strongly associated with obesity than with obesityrelated metabolic disorders in Jamaican adults. International Journal of Obesity, 2004: 543-550

4. Bogers RP, Bemelmans WJ, \& Hoogenveen RT. Association of overweight with increased risk of coronary heart disease partly independent of blood pressure and cholesterol levels: a meta-analysis of
21 cohort studies including more than 300,000 persons. Arch Intern Med. 2007. 167, 1720-8

5. Centers for Disease Control and Prevention Division of Media Relations, Study Estimates Medical Cost of Obesity May Be as High as \$147 Billion Annually. 2009. Avaiable from: http://www.cdc.gov/media/pressrel/2009/r090727. html

6. World Health Organization. Obesity: Preventing and managing the global epidemic. 2000. Available from:

http://www.who.int/nutrition/publications/obesity/ WHO_TRS_894/en/

7. Geissler C, Powers H. Human Nutrition $11^{\text {th }}$ edition. Philadelphia: Sunder Elsevier; 2005.

8. Riset Kesehatan Dasar Provinsi Jawa Tengah. Badan Penelitian dan Pengembangan Kesehatan Departemen Kesehatan RI. 2007.

9. Riset Kesehatan Dasar. Badan Penelitian dan Pengembangan Kesehatan Kementerian Kesehatan RI. 2010.

10. Riset Kesehatan Dasar. Badan Penelitian dan Pengembangan Kesehatan Kementerian Kesehatan RI. 2013.

11. Saboo B, Talaviya $\mathrm{P}$, Chandarana $\mathrm{H}$, Shah $\mathrm{S}$, Chintal Vyas, Nayak H. Prevalence of Obesity and Overweight in Housewives and Its Relation With Household Activities and Socio-Economical Status. Journal of Obesity and Metabolic Research. 2014: $1 ; 20-24$.

12. Wareham NJ, Van Sluijs EMF, Ekelund U. Physical Activity and Obesity Prevention: A Review of The Current Evidence. Proceedings Of The Nutrition Society 2005; 64: 229-247

13. Goi Misrawatie. Korelasi Asupan Zat Gizi Makro Zat Gizi Mikro dan Aktifitas Fisik dengan Obesitas pada Mahasiswa Poltekkes Kemenkes Gorontalo. Gorontalo. 2012.

14. Mahan LK, Escott-Stump S, Raymond JL. Krause's Food and The Nutrition Care Process 13th edition. Philadelphia: Saunder Elsevier; 2012.

15. Diana R, Yuliana I, Yasmin G, Hardinsyah. Faktor Risiko Kegemukan pada Wanita Indonesia. Jurnal Gizi dan Pangan. 2013; 8(1): 1-8

16. Austin GL, Ogden LG, Hill JO. Trends in Carbohydrate, Fat, and Protein Intakes and Association with Energy Intake in Normal-Weight, Overweight, and Obese Individuals: 1971-2006. The American Journal of Clinical Nutrition. 2011;93:836-43

17. Esmaillzadeh A, Azadbakht L. Major Dietary Patterns in Relation to General Obesity and Central Adiposity among Iranian Women. The Journal of Nutrition. 2008; 138: 358-363.

18. Febriyani NMPS, Hardinsyah, Briawan D. Minuman Berkalori dan Kontribusinya Terhadap Total Asupan Energi Remaja dan Dewasa. Jurnal Gizi dan Pangan. 2012: 7(1); 35-42.

19. Bujnowski D, Xun P, Daviglus ML, Horn VL, He K, Stamler J. Longitudinal Association Between 
Animal and Vegetable Protein Intake and Obesity among Adult Males in The United States: The Chicago Western Electric Study. Journal American Diet Association. 2011: 111(8); 1150-1155.

20. Shayo GA, Mugusi FM. Prevalence of Obesity and Associated Risk Factors among Adults in Kinondoni Municipal District Dar Es Salaam Tanzania. BMC Public Health. 2011: 11; 365.

21. Cohen AK, Rehkopf DH, Deardorff J, Abrams B. Education and Obesity at Age 40 among American Adults. Soc Sci Med. 2013; 78: 34-41

22. Edelman A, Jensen JT, Bulechowsky M, Cameron J. Combined oral contraceptives and body weight: do oral contraceptives cause weight gain? A primate model. Human Reproduction 2011:26(2);330-336

23. Lopez LM, Edelman A, Chen-Mok A, Trussell J, Helmerhorst FM. Progestin-only contraceptives: effects on weight. John Wiley and Sons. 2011

24. World Health Organization. The Asia Pasific Perspective: Redefining Obesity and Its Treatment. 2000

25. IPAQ. Guidelines for Data Processing and Analysis of the International Physical Activity Questionnaire (IPAQ). 2005

26. Birth Control Methods. Avaiable from: http://peelregion.ca/health/sexuality/birthcontrol/pdfs/birth-control-methods.pdf

27. Surat Keputusan Upah Minimum Jawa Tengah. 2014. Tersedia di: http://betterwork.org/inlabourguide/wp-content/uploads/SK-UMK-Jateng2015.pdf

28. Murray RK, Granner DK, Rodwell VW. Biokimia Harper. Penerbit Buku Kedokteran. 2009

29. Gropper SS, Smith JL, Groff JL. Advanced Nutrition and Human Metabolism $5^{\text {th }}$ Edition. Wadsworth Cengage Learning. 2009

30. Keller U. Dietary proteins in obesity and in diabetes. International Journal for Vitamin and Nutrition Research.2011: 81(2-3):125-33.

31. Bekesinska ME, Smit JA, Guidozzi F. Weight Change and Hormonal Contraception: Fact and Fiction. Expert Rev of Obstet Gynecol. 2011;6(1):45-56.

32. Sriwahyuni E, Wahyuni CU. Hubungan antara Jenis dan Lama Pemakaian Alat Kontrasepsi Hormonal dengan Peningkatan Berat Badan Akseptor. Universitas Airlangga. 2009

33. Adult Obesity and Socioecomonic Status. National Obesity Obervatory. 2012. Available from: http://www.noo.org.uk/uploads/doc/vid_16966_Ad ultSocioeconSep2012.pdf 